\title{
PROBLEM POSING LEARNING UNTUK MENINGKATKAN HASIL BELAJAR SISWA
}

\author{
Lina Marlina ${ }^{1}$, Udi Hamzah²) \\ Universitas Banten Jaya \\ Serang, Indonesia \\ linamarlina@unbaja.ac.id ${ }^{1)}$,udihamzah@unbaja.ac.id ${ }^{2)}$
}

\begin{abstract}
The research problem of this classroom action research is the low achievement to learn civics class XA SMA ALHusen City of Tunjung Teja in the academic year 2017. The purpose of this research is to increase the students' achievement on the subjects of civic education. The results of this research for the school is to improve the quality of civic education, besides that it is also useful for teachers and students. By doing classroom action research the teachers get experience in conducting the learning more interesting and enjoyable. This research implemented in three cycles, where each cycle includes the activities of planning, action, observation and reflection. The Subjects of the research are students of class XA as many as 28 students. The troubleshooting method used is to apply model problem posing learning on the subjects of civic education, the instruments of the research is using observation sheet increase student achievement. Implementation of the research conducted collaboratively with teachers as implementers and researchers act as an observer. The results of this research shows increased student achievement. The cycle I with an average of 53,58. The cycle II with an average 61,76. The cycle III with an average 80,26 Therefore this classroom action research is successful so the researchers recommended the implementation of model problem posing learning can be increasing the students' learning outcomes on the subjects of civic education.
\end{abstract}

Keyword : Problem Posing Learning, Students, Learning Outcomes.

\section{PENDAHULUAN}

Dalam konteks, tujuan pendidikan nasional dewasa ini warga negara yang baik adalah yang bersenergi dengan pendidikan kewarganegaraan yaitu warganegara yang demokratis bertanggung jawab (pasal 3) dan warga negara yang memiliki semangat kebangsaan dan cinta tanah air (pasal 37 undang- undang No 20 tahun 2003). Berkenaan dengan pendapat tersebut dapat disimpulkan bahwa tujuan pendidikan pancasila dan kewarganegaraan di sekolah bertujuan untuk mengembangkan kemampuan dan membentuk watak serta peradaban bangsa yang bermartabat dalam rangka mencerdaskan kehidupan bangsa, bertujuan untuk berkembangnya potensi peserta didik agar menjadi manusia yang beriman dan bertakwa kepada Tuhan Yang Maha Esa, berakhlak mulia, sehat, berilmu cakap, kreatif, mandiri, dan menjadi warganegara yang demokratis, bertanggung jawab, memiliki semangat kebangsaan serta cinta tanah air. (Hamid Darmani; 16, Urgensi, Alfabeta). Untuk mengetahui penerapan model pembelajaran problem posing learning (pengajuan masalah) pada mata pelajaran pendidikan dan 
kewarganegaraan di kelas X 1 SMA Al-Husen Tunjung Teja. Serta Untuk mengetahui peningkatan hasil belajar siswa dengan menggunakan model pembelajaran problem posing learning (pengajuan masalah) di kelas $X 1$ SMA Al-Husen Tunjung Teja. Ada tiga kategori utama atau kerangka filosofis mengenai teori - teori belajar, yaitu: teori belajar behaviorisme, teori belajar kognitifisme, dan teori belajar konstruktivisme hanya berfokus pada aspek obyektif di amati pembelajaran. belajar sebagai sebuah proses dimana pelajar aktif menbangun atau membangun ide - ide baru atau konsep.

\section{a. Teori belajar behaviorisme}

Teori behaviorisme adalah sebuah teori yang di cetuskan oleg gage dan berliner tentang perubahan tingkah laku sebagai hasil dari pengalaman. Teori ini lalu berkembang menja aliran psikologi belajar yang berpengaruh terhadap arah pengembangan teori dan praktis pendidikan dan pembelajaran yang di kenal sebagai aliran behavioristik.

\section{b. Teori belajar kognitifisme}

Model kognitif ini memiliki persfektif bahwa para peserta didik memproses informasi dan pelajaran melalui upayanya mengorganisir, menyimpan, dan kemudian menemukan hubungan antara pengetahuan yang telah ada. Model ini menekankan pada bagian informasi di proses.

\section{c.Teori belajar konstruktivisme}

Konstruksi berarti bersifat membangun dalam konteks filsafat pendidikan dapat di artikan konstruktivisme adalah suatu upaya membangun tata susunan hidup yang berbudaya modern. Konstruktivisme merupakan landasan berfikir (filosofi) pembelajaran konstektual yaitu bahwa pengetahuan di bangun oleh manusia sedikit demi sedikit yang hasilnya di perluas melalui konteks yang terbatas dan tidak sekonyong - konyong pengetahuan bukanlah seperangkat fakta - fakta, konsep, atau kaidah yang siap untuk di ambil dan di ingat. Manusia harus mengkontruksi pengetahuan itu dan memberi makna melalui pengalaman nyata. Belajar adalah proses interaksi dengan lingkungan dimana interaksi pada dasarnya adalah pengalaman. Oleh karena itu dalam setiap proses belajar selalu menunjukan adanya keterlibatan langsung individu dengan hal yang di pelajarinya, atau pengalaman dengan demikian,proses belajar tidak bisa di wakilkan pada orang lain implikasibagi guru adalah harus bisa merekayasa suatu pengalaman belajar yang efektif, berkesan, dan menyenangkan agar hasil proses belajar bisa berjalan 
dengan baik, dan hasil belajarnya bisa bertahan lama (Deni Kurniawan, 18:2014). Belajar adalah proses menghadapi dan menjalani tantangan untuk mencapai suatu tujuan, pemenuhan kebutuhan atau pemenuhan kepuasan tertentu. Oleh karena itu, agar sukses memenuhi tantangan medan di perlukan daya tahan, disiplin, dan kesabaran implikasi bagi guru adalah perlu mengkreasi situasi dan kondisi yang bisa mengembangkan afeksi disiplin, daya tahan, dan kesabaran siswa selama proses belajar mengajar (Deni Kurniawan, 18:2014).

Proses belajar atau perubahan prilaku ada proses balikan atau penguatan dari luar atas respon yang di berikan individu. Balikan dan penguatan ini berfungsi untuk memperkuat prilaku yang di inginkan dan menghilangkan prilaku yang tidak di inginkanatau salah. Proses ini berlangsung selama proses belajar terjadi imflikasi atas prinsip ini adalah, guru perlu memberikan balik atau feed back atas prilaku belajar yang di tunjukan siswanya (Deni Kurniawan, 18:2014).

Pendidikan pancasila PPkn (kurikulum 1994) yang dalam kurikulum 2006 di sebut pendidikan kewarganegaraan dan dalam kurikulum 2013 kembali menjadi nama menjadi Pendidikan Pancasila dan Kewarga negaraan berawal dari perjalanan sejarah panjang bangsa indonesia yang di mulai sejak dari perebutan dan mempertahankan kemerdekaan sampai mengisi kemerdekaan, bahkan terus berlangsung sampai jaman reformasi saat ini. Kondisi perebutan danpertahanan kemerdekaan itu di sikapi oleh bangsa indonesia berdasarkan kesamaan nilai nilai perjuangan bangsa yang senantiasa tumbuh dan berkembang. Kesamaan nilainilai tersebut di landasi oleh jiwa, tekad dan semangat nasional kebangsaan. Kesemuanya itu tumbuh dan berkembang menjadi kekuatan yang mampu mendorong proses terwujudnya Negara Kesatuan Republik Indonesia (NKRI) yang tangguh. Pendidikan Pancasila dan Kewarganegaraan (citizenship education) memiliki peran yang amat penting dalam kehidupan berbangsa dan bernegara. Pendidikan kewarganegaraan menyangkut persoalan jati diri dan identitas suatu bangsa. Pendidikan pancasila dan kewarganegaraan berkontribusi memberikan arah tujuan berbangsa dan bernegara indonesia. Pendidikan Pancasila dan Kewarganegaraan secara sistematik ingin mewujudkan fungsi dan tujuan pendidikan nasional berdasarkan pancasila dan UUD 1945. Pendidikan pancasila dan kewarganegaraan bertujuan untuk membekali generasi muda selaku penerus 
cita - cita bangsa yang dengan kesadaran tinggi memiliki jiwa bela negara serta kemampuan berfikir secara konprensif integral dalam rangka mewujudkan ketahanan nasional yang tangguh. Kesadaran bela negara ini berwujud sebagai kerelaan dan kesadaran melakukan kelangsungan hidup bangsa dan bernegara melalui bidang profesinya masing masing, dengan demikian kesadaran bela negara mengandung pengertian:

a. Kecintaan kepada tanah air

b. Kesadaran berbangsa dan bernegara

c. Kenyakinan akan pancasila dan UUD 1945

d. Kerelaan berkorban bagi bangsa dan Negara

e. Memiliki sikapdan prilaku bela negara Kemampuan berpikir konprehensif integral adalah kemampuan berpikir tentang sesuatu dalam kaitannya dengan keseluruhannya, dimana jika kita melihat suatu peristiwa di masyarakat kita tidak memandang peristiwa itu menurut pandangan individu/golongan, melainkan berbadasar pandangan kepentingan bersama yaitu kepentingan masyarakat/bangasa dan negara dari berbagai aspek kehidupan. Dengan pendidikan kewarganegaraan setiap warga negara indonesia umumnya dan generasi muda khususnya di harapkan akan tumbuh wawsan dan kesadaran berbangsa, bernegara, bersikap serta berprilaku cinta tanah air yang bersendikan kebudayaan, wawasan nusantara serta ketahanan nasional dalamdiri setiap warga negara indonesia dalam bingkai negara kesatuan Republik Indonesia. (Hamid Darmani;2014:15, Alfabeta).

\section{Tujuan Pendidikan Pancasila Dan}

\section{Kewarganegaraan}

Untuk mewujudkan sistem pertahanan negara, di selenggarakan usaha pembangunan dan membina kemampuan, daya tangkal negara dan bangsa serta menanggulangani setiap ancaman yang di selenggarakan oleh pemerintah dan di persiapkan secara dini. Sistem pertahanan negara dalam menghadapi ancaman militer menempatkan Tentara Nasional Indonesia sebagai komponen utama dengan di dukung oleh komponen cadangan dan komponen pendukung. (Hamid Darmani; 2014, 69 urgensi)

\section{Ruang Lingkup Pembelajaran PPKn}

Ruang lingkup PPKn meliputi aspek - aspek sebagai berikut. negara kesatuan republik indonesia, keterbukaan dan jaminan keadilan.

(a) Norma Hukum Dan Peraturan meliputi: tertib dalam kehidupan yang tertib lingkup keluarga dan tertib di lingkungan sekolah serta masyarakat berbangsa dan bernegara. 
(b) Hak Asasi Manusia, meliputi: hak dan kewajiban anak, hak dan kewajiban anggota masyarakat, instrumen nasional dan internasional HAM, pemajuan, penghormata dan perlindungan HAM. Kebutuhan Warga negara meliputi: hidup gotong royong, harga diri sebagai warga masyarakat, kebebasan berorganisasi, kemerdekaan mengeluarkan pendapat, menghargai keputusan bersama, prestasi diri, persamaan kedudukan warganegara.

(c) Konstitusi Negara meliputi: proklamasi kemerdekaan dan konstitusi yang pertama, konstitusi konstitusi yang pernah di gunakan di Indonesia, hubungan dasar negara dengan konstitusi.

(d) Kekuasaan Dan Politik meliputi: pemerintahan desa dan kecamatan, pemerintah dan otonomi, pemerintah pusat, demokrasi dan sistem politik, budaya politik, budaya demokrasi menuju masyarakat madani, sistem pemerintahan,pers dalam masyarakat demokrasi.(Hamid Darmani; 29. Urgensi)

\section{Model pembelajaran Problem Posing} Learning (pengajuan masalah)

Problem posing learning (pengajuan masalah) merupakan model pembelajaran yang mengharuskan siswa menyusun pertanyaan sendiri atau memecah suatu soal menjadi pertanyaan-pertanyaan yang lebih sederhana. Diharapkan pembelajaran dengan model problem posing learning (pengajuan masalah) dapat meningkatkan hasil belajar, sehingga pembelajaran yang aktif akan tercipta, siswa tidak akan bosan dan akan lebih tanggap. Dengan begitu akan memengaruhi hasil belajarnya dan akan menjadi lebih baik . (Aris Soimin,2014 : 133).

Problem posing learning (pengajuan masalah) memiliki beberapa pengertian. Pertama, Perumusan soal sederhana atau perumusan soal yang ada dengan beberapa perubahan agar lebih sederhana dan dapat dipahami dalam memecahkan soal yang rumit. Kedua, perumusan soal yang berkaitan dengan syarat-syarat pada soal yang telah diselesaikan untuk mencari alternatif pemecahan lain. Pembelajaran dengan model pemberian tugas pengajuan soal (problem posing learniing) pada intinya meminta siswa untuk mengajukan soal atau masalah. Permasalahan yang diajukan dapat berdasarkan pada topic yang luas, masalah yang sudah di kerjakan, atau imformasi tertentu yang diberikan oleh guru. Apabila dikaitkan dengan peningkatkan kemampuan siswa, pengajuan soal merupakan pada membaca 
suatu imformasi yang diberikan dan menginformasikan pertanyaan secara verbal maupun tertulis. Salah satu usaha untuk memperbaiki proses pembelajaran tersebut adalah dengan menggunakan model pembelajaran Problem Posing Learning (pengajuan masalah). Problem posing learning (pengajuan masalah) merupakan model pembelajaran yang mengharuskan siswa menyusun pertanyaan sendiri atau memecah suatu soal menjadi pertanyaan-pertanyaan yang lebih sederhana. Diharapkan pembelajaran dengan model problem posing learning (pengajuan masalah) dapat meningkatkan hasil belajar, sehingga pembelajaran yang aktif akan tercipta, siswa tidak akan bosan dan akan lebih tanggap. Dengan begitu akan memengaruhi hasil belajarnya dan akan menjadi lebih baik . (Aris Soimin,2014 : 133). Problem Posing Learning (pengajuan masalah) adalah sebuah model pembelajaran yang dapat membantu guru dan siswa dalam meningkatkan hasil belajar di sekolah, dalam penerapannya model pembelajaran ini disajikan dengan cara yang menyenangkan, santai, dan menarik sehingga pelajaran mudah diterima oleh siswa, dengan penerapan yang menarik siswa termotivasi mengikuti pembelajaran yang menjadikan siswa aktif belajar di dalam kelas sehingga hasil belajar siswa menjadi baik.. Disini penulis menggunakan model pembelajaran Problem Posing Learning (pengajuan masalah). yang diharapkan dapat membuat motivasi belajar siswa terhadap mata pelajaran Pendidikan Pancasila dan Kewarganegaraan menjadi meningkat dan tidak membosankan lagi. Model pembelajaran problem posing learning (pengajuan masalah) diharapkan siswa akan lebih mudah memahami pelajaran pendidikan Pancasila dan kewarganegaraan, sehingga tercapai hasil belajar optimal. Dengan belajar dalam kelompok-kelompok kecil siswa dapat bertanya tentang hal-hal yang belum di pahami kepada teman atau guru tanpa rasa takut, malu, maupun rendah diri sehingga pemahaman siswa terhadap suatu konsep diharapkan terjadi peningkatan dalam hasil belajar siswa. Salah satu model yang di terapkan dalam pembelajaran, adalah model pembelajaran problem posing learning (pengajuan masalah). Model pembelajaran problem posing learning (pengajuan masalah) dapat meningkatkan hasil belajar siswa baik untuk mengembangkan kopetensi secara perorangan maupun kelompok. Hasil belajar adalah mencakup tiga aspek dalam proses pembelajaran yaitu. 
Keterampilan,kebiasaan,pengetahuan dan pengertian, sikap dan cita-cita. Menurut (purwanto, 2009:47) hasil belajar adalah suatu cara evaluasi yang dimaksud sebagai cermin untuk melihat kembali apakah tujuan yang di tetapkan telah tercapai dan apakah tujuan yang di tetapkan telah tercapai dan apakah proses belajar mengajar telah berlangsung evektif untuk memperoleh hasil belajar. Masalah utama dalam pembelajaran pendidikan pancasila dan kewarganegaraan ialah kurangnya keaktifan belajar siswa sehingga menyebabkan kurangnya pengetahuan pendidikan kewarganegaraan. pada proses kegiatan belajar siswa kurang aktif dalam pembelajaran, siswa tidak aktif bertanya, tidak aktif menjawab pertanyaan, masih terpengaruh situasi di luar kelas, kurang demokratis, interaksi, dan guru lebih dominan dari pada siswa seingga pelajaran pendidikan kewarganegaraan cenderung menjadi mata pelajaran yang jenuh dan membosankan. Berdasarkan observasi yang di lakukan pada tanggal 02 Mei 2017 di kelas X 1 SMA AL-Husen Tunjung Teja di ketahui bahwa siswa kurang aktif dalam pembelajaran seperti siswa tidak bertanya, siswa tidak menjawab pertanyaan dari guru maupun teman dan masih terpengaruh situasi di luar kelas serta kurangnya interaksi antara siswa dengan siswa, siswa dengan guru.

\section{METODE PENELITIAN}

\section{Waktu dan Tempat Penelitian}

Penelitian dilakukan di sekolah SMA AlHusen Tunjung Teja pada kelas X 1. Waktu penelitian direncanakan pada semester II tahun pelajaran 2016-2017 selama bulan april sampai dengan bulan mei 2017. Kegiatan meliputi kegiatan persiapan, pelaksanaan, waktu dan kegiatan, yang terdiri dari kopetensi dasar menjelaskanhakikat kemerdekaan mengemukakan pendapat, menguraikan pentingnya kemerdekaan, mengemukakan pendapat secara bebas dan tanggung jawab. Waktu penelitian akan di gunakan secara efektif dan efisien. Subyek penelitian di kelas $X 1$ dengan jumlah siswa 28. Siswa Laki - laki 13 dan siswi perempuan 15.

\section{Desain Penelitian}

Desain yang di gunakan ialah penelitian tindakan kelas (PTK) penelitian tindakan kelas menurut Suharsimin Arikunto (2008.3 - 8). Penelitian tindakan kelas (PTK) merupakan suatu perencanaan terhadap kegiatan belajar berupa sebuah tindakan, tindakan yang sengaja di munculkan dan terjadi dalam sebuah kelas secara bersama. Adapun prinsip - prinsip dalam sebuah penelitian tindakan 
kelas yaitu: kegiatan nyata dalam situasi rutin adanya kesadaran diri untuk memperbaiki kinerja. Untuk memperjelas variable penelitian, Maka model yang di pakai dalam penelitian tindakan kelas (PTK) pada gambar seperti di bawah ini

\section{Gambar 3.1}

Alur Penelitian Tindakan Kelas

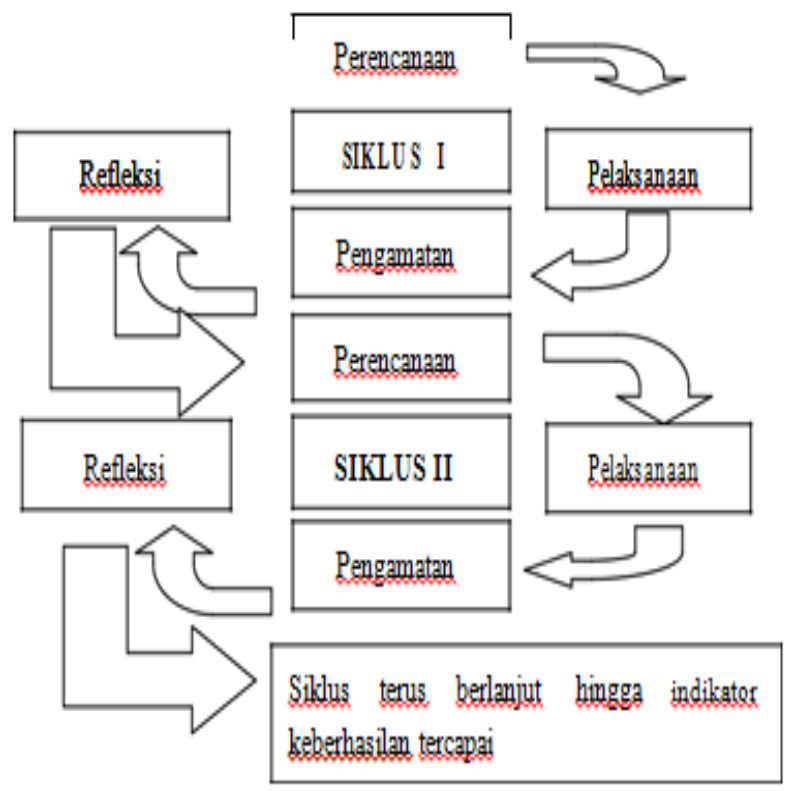

\section{Sumber: Suharsimi Arikunto (2012:18)}

Dari uraian di atas maka dapat di simpulkan model penelitian tindakan kelas (PTK) Menurut Suharsimin Arikunto bisa berjalan sesuai dengan apa yang di harapkan karna melalui proses siklus - siklus yang di mulai dari perencanaan, tindakan, pengamatan, dan refleksi. Setelah itu barulah memulai tahapan evaluasi untuk melihat perkembangan Hasil Belajar siswa yang memuaskan.

\section{Prosedur Penelitian}

Prosedur penelitian yang di gunakan adalah menggunakan siklus berulang dan berkelanjutan yang berpatokan pada model yang di temukan oleh Suharsimin Arikunto. Penggunaan model ini di harapkan dapat meningkatkan hasil belajar siswa. Model ini terdiri dari empat tahap yaitu perencanaan,tindakan,observasi dan refleksi.

\section{Siklus I}

\section{Perencanaan}

Dalam perencanaan pelaksanaan penelitian mencakup beberapa kegiatan antara lain. Permintaan izin kepada kepala sekolah SMA AL-HUSEN Tunjung Teja. Observasi dan wawancara di lakukan untuk mengetahui awal mengenai situasi,kondisi dan proses pembelajaran Pendidikan Pancasila dan Kewarganegaraan kususnya di kelas X 1 SMA AL-HUSEN Tunjung Teja. Kegiatan observasi meliputi pengamatan terhadap sikap dan prilaku siswa dan guru saat berlangsungnya proses pembelajaran serta kemampuan siswa dalam menerima dan memahami materi pembelajaran yang telah di sampaikan. Indentifikasi masalah di lakukan terhadap kegiatan pembelajaran di dalam kelas yang di sarankan perlu adanya perubahan. Kegiatan selanjutnya dalamtahap perencanaan adalah 
merumuskan strategi, model, metode, materi, alat dan media yang akan di gunakan dalam setiap tindakan. Perumusan ini di lakukan untuk meningkatkan hasil belajar siswa di kelas $\mathrm{X} 1$ SMA AL-HUSEN Tunjung Teja. Terhadap materi dengan pokok bahasan menampilkan perilaku kemerdekaan mengemukakan pendapat. Membuat perencanaan pembelajaran pada tahap ini peneliti menyusun rencana kegiatan pembelajaran RPP. Instrumen penelitian pada saat tindakan sangat di perlukan. Instrumen yang di gunakan dalam penelitian berupa hasil tes tertulis,observasi dan wawancara

\section{a. Pelaksanaan}

Pelaksanaan di sesuaikan dengan rencana yang telah di buat sebelumnya. Adapun pelaksanaan model pembelajaran kooperatif tipe problem posing learning (pengajuan masalah) yaitu:

Langkah 1 persiapan Dalam tahap ini Lembaran materi yang di sesuaikan dengan model pembelajaran kooperatif tipe problem posing learning (pengajuan masalah).

Langkah 2 menerangkan materi Guru menjelaskan materi pembelajaran kepada para siswa menggunakan alat peraga untuk memperjelas konsep sangat di sarankan.
Langkah 3 memberikan soal Guru memberikan latihan soal secukupnya

Langkah 3 mengajukan masalah dan memecahkannya Siswa diminta mengajukan 1 atau 2 buah soal yang menantang. Dan siswa yang bersangkutan harus mampu menyelesaikannya.

Langkah 4 mengumpulkan masalah temuan siswa Guru menyuruh siswa unuk menyajikan soal temuannya di depan kelas

Langkah 5 memberikan tugas rumah (PR) Guru memberikan tugas rumah secara individu.

\section{Observasi}

Observasi di laksanakan selama pembelajaran berlangsung dan guru sebagai pelaksana dan peneliti menjadi observer untuk menemukan titik kelemahan serta perkembangan dalam proses pembelajaran yang di lakukan oleh siswa.

\section{Refleksi}

Kegiatan refleksi di lakukan dengan cara melihat hasil analisis pelaksanaan pembelajaran yang tercatat pada hasil belajar siswa. Hasil dari refleksi di gunakan sebagai bahan perbaikan dalam merencanakan tindakan selanjutnya.

\section{Teknik Pengumpulan Data}

Teknik yang digunakan dalam mengumpulkan data penelitian tindakan kelas (PTK). Yaitu 
melalui tes hasil belajar dan non tes berupa observasi. Pengumpulan data di lakukan menganalisis dan memastikan bahwa data yang benar sesuai dengan kenyataan dan sesuai dengan tujuan yang telah di tetapkan. Teknik pengumpulan data yang di gunakan antara lain:

\section{Observasi}

Lembar observasi untuk mengukur tinggi hasil belajar siswa dalam proses belajar pendidikan pancasila dan kewarga negaraan, dalam skripsi ini penulis melakukan observasi di kelas X A SMA Al-HusenTunjung Teja.

\section{Tes Hasil Belajar}

Tes hasil belajar ini di lakukan ketika proses pembelajaran selesai di laksanakan. Tes hasil belajar ini di lakukan dalam bentuk tertulis. Soal hasil belajar berupa tes tertulis ini di lakukan untuk mengetahui sejauh mana pengetahuan serta pemahaman materi pada mata pelajaran pendidikan pancasila dan kewarganegaraan. Suharsimi Arikunto (2006: 172). Pada tes hasil belajar penulis melakukan tes pada siswa dan siswa kelas X A SMA AlHusen Tunjung Teja

\section{Wawancara}

Menurut Sugiono (2014:137) wawancara di gunakan sebagai teknik pengumpulan data apabila penelitian ingin melakukan studi pendahuluan untuk menemukan permasalahan yang harus di teliti, dan juga apabila peneliti ingin mengetahui. Hal - hal dari responden yang lebih mendalam dan jumlah respondennya sedikit atau kecil, teknik pengumpulan data mendasarkan diri pada laporan tentang diri sendiri atau self-report, atau setidak - tidaknya pada pengetahuan atau keyakinan pribadi. Wawancara terhadap guru, kepala sekolah, siswa dan siswi kelas X A SMA Al-HusenTunjung Teja.

\section{Dokumentasi}

Dokumentasi di gunakan untuk memperkuat data yang di peroleh dalam observasi. Dalam penelitian ini dokumentasi di gunakan untuk mengetahui keadaan kelas pada saat pembelajaran menggunakan pembelajaran problem posing learning (pengajuan masalah).

\section{Teknik analisis data}

Teknik analisis data yqng peneliti lakukan di sekolah yaitu dengan menggunakan tes hasil belajar siswa. Dimana dalam teknik ini terdapat kegiatan mencermati dan menguraikan serta mengaitkan setiap informasi yang terkait dengan kondisi awal, proses belajar dan hasil belajar untuk memperoleh kesimpulan tentang keberhasilan tindakan perbaikan pembelajaran. 
1. Reduksi data (memilih data)

Reduksi data merupakan proses merangkum, memilih hal yang penting dan memfokuskan pada hal yang di rasa penting, di cari pola dan temannya.

\section{Display data (memaparkan data)}

Display data berarti menyajikan data dalam bentuk uraian singkat, bagan, hubungan antara kategori dan sebagainya.

\section{Mengambil kesimpulan dan verifikasi data}

Mengambil kesimpulan dan verifikasi merupakan proses perumusan makna dari hasil penelitian yang di lakukan dalam di ungkapkan dengan kalimat yang singkat, padat dan mudah di pahami serta di lakukan dengan cara berulang kali, melakukan peninjauan mengenai kebenaran dan penyimpulan itu, kususnya berkaitan dengan relevansi dan konsistennya terhadap judul, tujuan dan perumusan masalah yang ada. Dengan menggunakan pedoman observasi, kemudian di cari skor rata - rata aktivitas siswa dan guru akan di baagi menjadi lima katagori yaitu: baik sekali, baik, cukup, kurang dan buruk. Adapun instrumen observasi yang di gunakan adalah skala Guttman menurut sugiyono (2012:96). Dilakukan bila ingin mendapat jawaban yang tegas terhadap suatu permasalahan yang di nyatakan. Skala Guttman selain dapat di buat dalam bentuk pilihan ganda, juga dapat di bentuk dalam bentuk checklis. Dapat di buat skor tinggi satu dan terendah nol.

\section{HASIL PENELITIAN PEMBAHASAN}

\section{HASIL PENELITIAN}

\section{Deskripsi Awal}

Penelitian tindakan kelas dilaksanakan pada tanggal 02 April 2017 sampai dengan 29 Mei 2017 dikelas X 1 SMA AL-HUSEN Tunjung Teja, pada tahun ajaran 2016 - 2017 dengan jumlah siswa 28 terdiri dari 13 siswa laki- laki dan 15 siswa perempuan. Penelitian tindakan kelas di sebanyak tiga siklus, siklus pertama di lakukan dengan dua kali pertemuan, dan pada siklus kedua di lakukan dua kali pertemuan, pada setiap pertemuan dengan waktu (2x45) yang masing-masing siklus terdiri dari perencanaan, pelaksanaan, observasi, dan refleksi. Pada pertemuan pertama di adakan wawancara agar dapat mengetahui sejauh mana hasil belajar siswa sebelum di terapkan model pembelajaran problem posing learning (pengajuan masalah) dan pada setiap akhir siklus dilakukan post tes dan refleksi sebagai acuan dan masukan untuk pelaksanaan pembelajaran siklus selanjutnya. Penerapan model pembelajaran problem posing learning (pengajuan masalah) pada pembelajaran pendidikan pancasila dan 
kewarganegaraan dalam penelitian ini belum pernah dilakukan sebelumnya di kelas $\mathrm{X} 1$ SMA AL-HUSEN Tunjung Teja, siswa kurang aktif dan hasil belajar pun kurang memuaskan karena pembelajaran berpusat kepada guru. Oleh karena itu peneliti mencoba menggunakan model pembelajaran problem posing learning (pengajuan masalah) pada pembelajaran pendidikan pancasila dan kewarganegaraan dengan harapan siswa akan lebih aktif dan dapat meningkatkan hasil belajar siswa.

\section{Pelaksanaan Siklus I}

Penelitian siklus 1 di bagi menjadi empat yaitu: Perencanaan, Pelaksanaan, Observasi dan Refleksi.

\section{Perencanaan}

a. Menyiapkan silabus

b. Menyiapkan rencana pelaksanaan pembelajaran (RPP)

c. Menetapkan materi bahan ajar siklus 1

d. Menyiapkan instrumen observasi, untuk melihat bagaimana situasi belajar mengajar ketika model pembelajaran di aplikasikan.

\section{Pelaksanaan}

a. Mengucapkan salam

b. Mengkondisikan siswa dan kelas mengabsen siswa

c. Memberi tahu materi yang akan di pelajari d. Menjelaskan materi

e. Memberi penjelasan tentang model pembelajaran problem posing learning (pengajuan masalah).

\section{Observasi}

Selama pembelajaran berlangsung dan guru sebagai palaksana danpeneliti menjadi observer untuk menentukan titik kelemahan serta perkembangan dalam proses pembelajaran yang di lakukan oleh siswa.

\section{Refleksi}

Dilakukan dengan cara melihat hasil analisis pelaksanaan pembelajar yang tercatat padahasil belajar siswa.

\section{Hasil observasi Siklus I}

Peneliti sebagai observer mengamati proses pembelajaran PKn di bantu oleh guru mata pelajaran PKn. Pembelajaran dilaksanakan dengan materi sistem politik, menggunakan model pembelajaran problem posing learning (pengajuan masalah) dikelas $\mathrm{X}$. penelitian mengambil posisi di belakang kelas di bangku yang telah d sediakan oleh murid, sedangkan guru kelas berada di bangku meja depan dengan harapan agar peneliti jelas melihat (mengamati) proses belajar mengajar PKn pada hari itu. Dari kegiatan tersebut, deskripsi tentang jalannya proses pembelajaran PKn dengan materi sistem politik menggunakan model pembelajaran problem posing learning (pengajuan masalah) sudah di jelaskan secara 
rinci dalam pelaksanaan tindakan pertama. Berdasarkan hasil pengamatan terhadap pelaksanaan proses belajar mengajar $\mathrm{PKn}$, diperoleh gambaran tentang hasil belajar siswa selama kegiatan belajar mengajar berlangsung, yaitu sebagai berikut.

Tabel 4.1 Hasil Observasi Penilaian Hasil Belajar Siswa Siklus I

\begin{tabular}{|c|c|c|}
\hline NAMA & $\begin{array}{c}\text { SKOR } \\
\text { AKHIR }\end{array}$ & $\begin{array}{c}\text { KETERANG } \\
\text { AN }\end{array}$ \\
\hline ADAM FIRDAUS & 45 & Kurang \\
\hline AHMAD КНОТIB & 53 & Kurang \\
\hline AJI SUPRIATNA & 56 & Sedang \\
\hline ALIPAH & 47 & Kurang \\
\hline AMINAH & 40 & Kurang \\
\hline ANDINI APRIYANTI & 67 & Sedang \\
\hline ANI NURJANAH & 80 & Baik \\
\hline ANISA & 73 & Sedang \\
\hline ASMAT & 42 & Kurang \\
\hline ATIKA & 50 & Kurang \\
\hline BUDI HER,AWAN & 63 & Sedang \\
\hline DEDEN KUSNAENI & 65 & Sedang \\
\hline ELIA & 53 & Kurang \\
\hline ENCEP IMANUDIN & 63 & Sedang \\
\hline ITI & 60 & Sedang \\
\hline KOSASIH & 43 & Kurang \\
\hline LITA IRAYANTI & & \\
\hline APRILIANI & 60 & Sedang \\
\hline MASRINA & 74 & Sedang \\
\hline MUHAMAD IRFAN & 65 & Sedang \\
\hline $\begin{array}{l}\text { NANDA YULIANTI } \\
\text { NUR HAERUL }\end{array}$ & 50 & Kurang \\
\hline FATUL & 40 & Kurang \\
\hline PUSKIAWATI & 80 & Baik \\
\hline RINA & 70 & Sedang \\
\hline ROHMAT & 70 & Sedang \\
\hline SITI KODIJAH & 33 & Kurang \\
\hline SITI ULPA & 54 & Kurang \\
\hline SUKRONI & 80 & Baik \\
\hline
\end{tabular}

$\begin{array}{ccc}\text { TAUFIK } & \mathbf{6 0} & \text { Sedang } \\ \text { Jumlah } & \mathbf{1 . 6 3 6} & \end{array}$

\section{Sumber: Purwanti (2008 : 75)}

Jumlah skor keseluruhan x 100

Jumlah siswa

$\frac{1.636}{28}=58.42$

Rentang Kriteria Hasil Pengamatan Hasil Belajar Siswa :

\begin{tabular}{cc}
\hline Kriteria & Skor \\
\hline $79-100$ & Baik \\
$56-78$ & Sedang \\
$33-55$ & Kurang
\end{tabular}

Dari data di atas maka dapat di simpulkan bahwa hasil belajar siswa dalam proses pembelajaran masih kurang dari apa yang di harapkan sebagai mana hasil yang di proleh adalah $58.42 \%$ di katakan sedang jika di lehat dari krieria keberhasilan siswa.

\section{Hasil penelitia siklus II}

Penelitian siklus II dilaksanakan pada tanggal 19 - 26. penelitian siklus II di bagi dalam empat kegiatan yaitu: perencanaan, pelaksanaan, observasi, refleksi.

\section{b. Perencanaan}

Perencanaan pada siklus I Pertemuan II meliputi kegiatan yang terdiri dari:

1) Menyiapkan silabus

2) Menyiapkan rencana pelaksanaan pembelajaran (RPP) 
3) Menetapkan materi bahan siklus I Pertemuan II

4) Menyiapkan soal tes sebanyak 10 butir soal

5) Menyiapkan instrumen observer, untuk melihat bagaimana situasi belajar mengajar ketika ketika model pembelajaran di aplikasikan.

\section{b. Pelaksanaan}

1) Mengucapkan salam

2) Mengkondisikan siswa dan kelas mengabsen siswa

3) Memberi tahu materi yang akan di pelajari

4) Menjelaskan materi

5) Memberi penjelasan tentang model pembelajaran problem posing learning (pengajuan masalah).

\section{c. Observasi}

Selama pembelajaran berlangsung dan guru sebagai palaksana danpeneliti menjadi observer untuk menentukan titik kelemahan serta perkembangan dalam proses pembelajaran yang di lakukan oleh siswa.

\section{d. Refleksi}

Dilakukan dengan cara melihat hasil analisis pelaksanaan pembelajar yang tercatat padahasil belajar siswa.

\section{Hasil observasi siklus II}

Dalam pembelajaran siklus II, siswa sudah mulai terbiasa dalam mengikuti pelajaran dengan model problem posing learning (pengajuan masalah). Hal nyata yang dapat di lihat adalah hasil pelaksanaan tindakan siklus II adalah terjadinya meningkatkan hasil belajar siswa. Berdasarkan hasil pengamatan terhadap palaksanaan proses belajar mengajar $\mathrm{PKn}$, diperoleh gambar tentang motivasi dan aktividas siswa selama kegiatan belajar mengajar berlangsung, yaitu sebagai berikut.

Tabel 4.2

Hasil Observasi Penilaian Hasil Belajar Siswa siklus II

\begin{tabular}{lcc}
\hline \multicolumn{1}{c}{ NAMA } & $\begin{array}{c}\text { SKOR } \\
\text { AKHIR }\end{array}$ & KET \\
\hline ADAM FIRDAUS & $\mathbf{8 0}$ & Baik \\
AHMAD KHOTIB & $\mathbf{9 0}$ & Baik \\
AJI SUPRIATNA & $\mathbf{8 0}$ & Baik \\
ALIPAH & $\mathbf{8 3}$ & Baik \\
AMINAH & $\mathbf{9 0}$ & Baik \\
ANDINI APRIYANTI & $\mathbf{8 0}$ & Baik \\
ANI NURJANAH & $\mathbf{8 3}$ & Baik \\
ANISA & $\mathbf{7 4}$ & Sedang \\
ASMAT & $\mathbf{8 0}$ & Baik \\
ATIKA & $\mathbf{8 0}$ & Baik \\
& & \\
BUDI HER,AWAN & $\mathbf{7 3}$ & Sedang \\
DEDEN KUSNAENI & $\mathbf{8 3}$ & Baik \\
ELIA & $\mathbf{8 0}$ & Baik
\end{tabular}




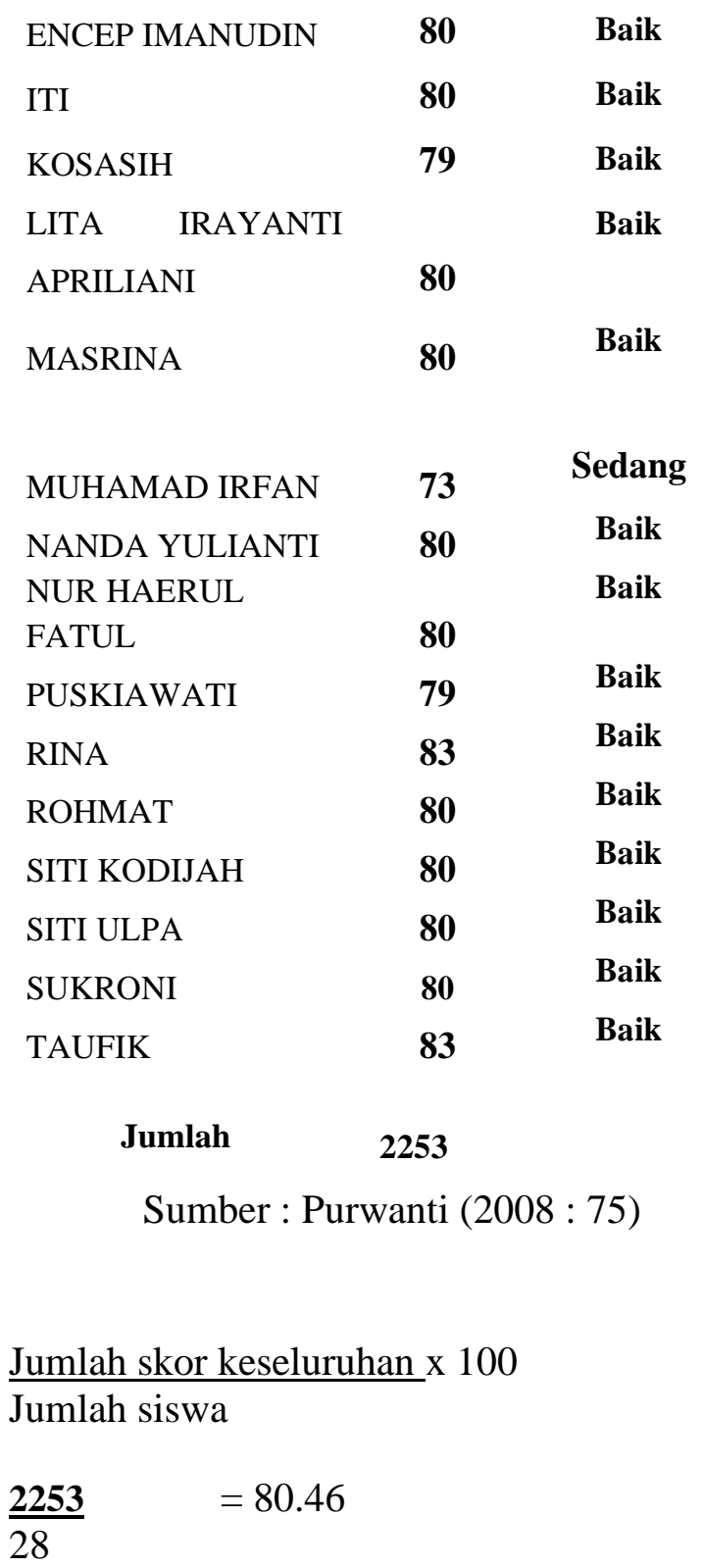

Untuk mengetahui aktivitas belajar siswa pada siklus II dalam penelitian ini di peroleh berdasarkan hasil dari lembar pengamatan siswa yang di ambil pada waktu proses pembelajaran dan diskusi kelompok berlangsung melalui penerapan model pembelajaran problem posing learning (pengajuan masalah). Dalam melakukan observasi peneliti menggunakan lembar observasi yang telah di siapkan di siapkan. Subyek yang di amati yaitu aktivitas siswa. Hasil observasi pada aktivitas mengajar guru dengan menggunakan model pembelajaran problem posing learning (pengajuan masalah) yaitu semua tahap telah di laksanakan dengan optimal, siswa juga sudah lebih aktif di bandingkan sebelumnya. Pada hasil analisis tes ini di dapat data yang berupa angka angka mengenai jumlah skor yang di peroleh masing - masing siswa terhadap soal tes yang di kerjakan setelah di terapkan model pembelajaran problem posinglearning (pengajuan masalah) dalam proses pembelajaran PKn. Data yang di peroleh melalui tes di hitung jumlah skor yang di peroleh masing - masing siswa dengan cara mengakumulasi masing - masing skor pada setiap item soal yang di kerjakan siswa. Berdasarkan hasil tes belajar siswa dapat di definisikan bahwa siswa yang sudah maju mengerjakan soal pilihan ganda dan esayy materi sistem politik, mendapat nilai 80.46 ke atas, sedangkan siswa lainnya belum sempurna dalam menyelesaikan soal yang di berikan. Berdasarkan hasil deskripsi penelitian dapat di gambarkan bahwa proses dalam pembelajaran pada mata pelajaran Pendidikan Pancasila Dan Kewarganegaraan siswa terlihat bahwa nilai hasil belajar siswa mendapat peningkatan pada setiap siklusnya. Dari hasil analisis peningkatan hasil nilai hasil 
pemahaman pelajaran Pendidikan Pancasila Dan Kewarganegaraan menggunakan model pembelajaran problem posing learning dapat meningkatkan hasil belajar siswa kelas X 1 SMA Al - Husen Tunjung Teja. Dimana siswa sudah terbiasa dengan model pembelajaran problem posing learning siswa juga lebih aktif, kreatif dan inovatif dan termotivasi dalam setiap pembelajaran dan sebagai siswa juga sudah meningkat hal ini dapat di lihat dari nilai hasil belajar di setiap siklusnya.

Tabel 4.10

Rekapitulasi hasil PTK penerapan model pembelajaran problem posing learning (pengajuan masalah) pada mata pelajaran pendidikan pancasila dan kewarganegaraan siswa kelas X1 SMA Al - Husen Tunjung Teja tahun pelajaran 2016 - 2017.

Ini artinya peningkatan pada pertemuan mencapai 11,3 dari pertemuan sebelumnya, pada siklus dua pertemuan ketiga dilakukan post test dan nilai hasil belajar siswa yang di dapat dengan nilai rata - rata 80,46 dari 28 siswa semua mencapai ketuntasan minimum, maka penelitian dengan penerapan model problem posing learning (pengajuan masalah) dapt di katakan berhasil. Dapat di simpulkan dengan demikian perbedaan hasil belajar siswa pada setiap siklus meningkat, sehingga kegiatan penelitian ini terdapat perubahan mempengaruhan peningkatan hasil belajar siswa di kelas $X 1$, nilai rata - rata pertemuan pertama mencapai 54.28 ini masih di bawah KKM, sedangkan pada pertemuan kedua mencapai 72.14 ini artinya sudah mencapai standar KKM dan pertemuan ketiga siklus II nilai - nilai yang di dapat 80.46 ini artinya sudah sesuai dengan standar kriteria ketuntasan minimal, berdasarkan data

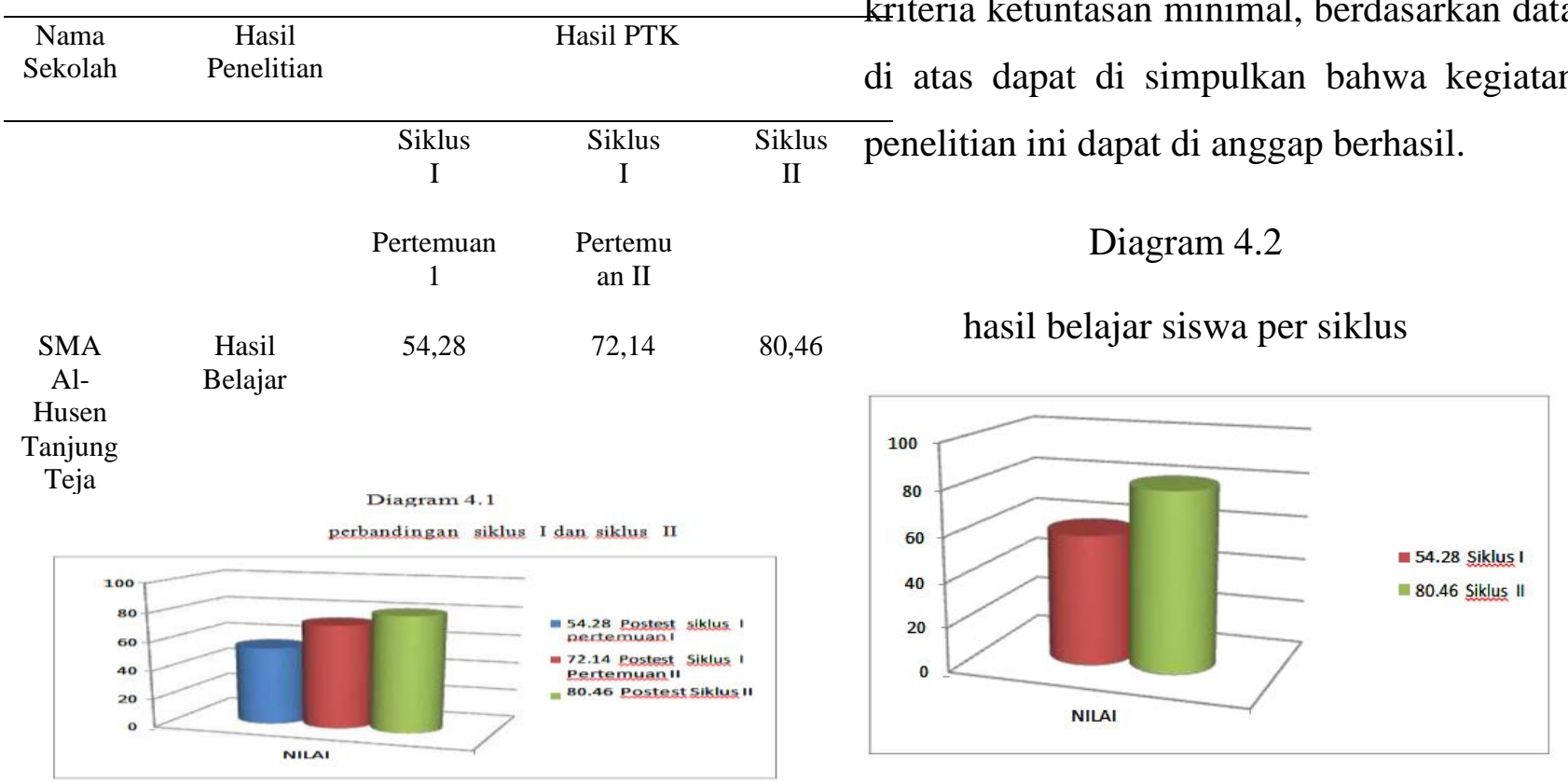


Berdasarkan diagram di atas maka hasil belajar siswa meningkat, hal yang terlihat darihasil yang di capai sisa pada instrumen hasil belajar pada siklus I ini mencapai yakni 65 dan siklus II mencapai 85 dari 28 siswa, perbedaan hasil belajar siswa merupakan sebuah bukti bahwa kegitan penelitian tindakan kelas ini telah berhasil di laksanakan, dengan demikian model pembelajaran problem posinglearning (pengajuan masalah) layak di gunakan dan di kembangkan pada mata pelajaran pendidikan pancasila dan kewarganegaraan (Ppkn) di sekolah menengah atas.

\section{SIMPULAN}

Berdasarkan hasil analisis dalam penelitian tindakan kelas yang di lakukan oleh peneliti dalam meningkatkan hasil belajar peserta didik melalui pembelajaran problem posing learning (pengajuan masalah) pada mata pelajaran Pendidikan Pancasila dan Kewarganegaraan dengan materi kesadaran berbangsa dan bernegara di kelas X1 SMA Al-Husen Tunjung Teja, dapat di simpulkan di bawah berdasarkan dari siklus I dan siklus II.

1. Penerapan model pembelajaran problem posing learning merupakan setrategi pembelajaran yang bermanfaat untuk mengetahui sejauh mana pemahaman siswa atas materi yang telah di berikan atau untuk mengetahui sejauh mana hasil belajar yang telah di capai siswa, serta dapat melihat kemampuan siswa dalam menyatakan pendapat dan berargumentasi sehingga hal ini dapat di pertanggung jawabkan model pembelajaran problem posing learning memberikan siswa untuk berfikir, berpendapat dan berkreasi secara mandiri.

2. Serta membantu siswa belajar berinteraksi, bekerjasama dalam kelompok, menghargai dan menghormati orang lain sesuai dengan nilai - nilai pembelajaran PKn pada siswa kelas X 1 di SMA Al - Husen Tunjung Teja.

3. Upaya mengatasi kendala dan hambatan yang di hadapi dalam pembelajaran problem posing learning pada mata pelajaran PKn di SMA Al- Husen Tunjung Teja sebagai Hasil belajar peserta didik berdasarkan hasil penelitian dari siklus I,II. Hasil belajar peserta didik pada materi sistem politik menggunakan model pembelajaran problem posing learning (pengajuan masalah) mengalami peningkatan, hal ini dapat dilihat dari setiap siklusnya mengalami peningkatan yaitu siklus I pertemuan 1 dengan rata - rata 70,71, sedangkan siklus II pertemuan I sudah mengalami peningkatan yaitu rata - rata 
81,42 . Dua nilai rata - rata sudah sangat meningkat.

\section{DAFTAR PUSTAKA}

Arikunto, Suharsimi. 2006. Prosedur Penelitian Suatu Pendekatan Praktik. Jakarta : Rineka cipta.

Arikunto, Suharsimi., dkk. 2008. Penelitian Tindakan Kelas. Jakarta: Bumi Aksara

Aris, shoimin. (2014). Model Pembelajaran Inovatif Dalam Kurikulum 2013. Yokyakarta: AR-ruz media

Darmadi, Hamid. (2014). Pendidikan Pancasila dan Kewarganegaraan di Perguruan Tinggi. Bandung: ALFABETA

Kurniawan, Deni. 2014. Pembelajaran Terpadu Tematik (Teori, Praktik, Dan Penilaian). Bandung: Alfabeta.

Purwanto.(2009).Evaluasi Hasil Belajar. Surakarta: Pustaka Belajar.

Shoimin, Aris. (2014). 68 Model Pembelajaran Inovatif Dalam Kurikulum 2013. Jakarta: AR-RUZZ MEDIA.

Sugiyono. (2014). Metode Penelitian Pendidikan Pendekatan Kuantitatif,
Kualitatif, dan R\&D. Bandung: Alfabeta.

Sugiyono. 2012. Metode Penelitian Kuantitatif Kualitatif dan R\&D. Bandung:Alfabeta.

Undang- Undang No 20 Tahun 2003 Pasal 37 